\title{
Centres Agronomiques de l'Université de Louvain au Congo
}

Wrrt the purpose of developing agriculture and the education of the native peasantry, Agricultural Centres were founded in the Belgian Congo in 1933; these centres have trained agricultural advisers, have organized schools of agriculture as well as practical training courses for farmers, and have established credit facilities. In carrying out its aims, C.A.D.U.L.A.C. has secured the co-operation of European agriculturalists and specialists, of missionary priests and teachers, and has endeavoured to adapt the ideas of European experts to the outlook of the Natives. By means of its agricultural schools it has succeeded in stemming the drift of the younger peasant population from the land to urban areas; 68 out of 106 former students have settled on their own land since the formation of the schools in $\times 939$.

\section{Élisabethville Anthropological Museum}

Tanganyika Notes and Records (June 1944) refers to an anthropological museum which has been created at Élisabethville through the initiative of Dr. Cabu, the well-known prehistorian of the Belgian Congo. In addition to a small but important collection of prehistoric stone imp!ements, there is an ethnological exhibition, and the museum has also a good collection of Bantu negro art, particularly of the Baluba, the Basonge, and the Tutshokwe.

\section{Société d'Etudes Camerounaises}

By a decree issued over the signature of the Secretary General at Douala in May 1944, the Société d' Études Camerounaises has been constituted a local centre of the Institut Français d'Afrique Noire; it is charged with the duty of carrying out researches in ethnology, geography, and natural sciences, of keeping, classifying, and expanding the archives and library of the territory, of establishing an information centre, of organizing a local museum, of holding conferences and exhibitions. Its scientific and technical staff is to be either recruited locally for special requirements, or may form part of the establishment of the I.F.A.N. Its expenses are to be a chatge on the local budget of the territory. It is also charged with the care and preservation of local monuments and historic sites, and the disposal of objects of scientific interest discovered or excavated in the territory.

The Bulletin of the Society, numéro 6, June 1944, contains an account of a visit made to Douala by Professor Monod, Director of I.F.A.N., for the purpose of effecting a rapprochement between the two organizations. During his stay at Douala, Professor Monod gave a public lecture on 'The Atlantic and Africa'.

\section{National Library of Ethiopia}

ON 5 May 1944 H.I.M. Haile Selassie formally opened the National Library of Ethiopia at Addis Ababa. The Emperor indicated in his speech that the aim of the Library was not only to gather together works of Ethiopian origin, but to collect, as far as it was possible, all books and material relating to that country, wherever published. As a beginning, the Librarian had undertaken the compilation of an inventory of all the manuscripts in Ethiopia, and all churches and monasteries are to be circularized with a request for information as to the manuscripts in their possession. In addition to establishing a complete collection of books (in all languages) on the history, literature, and ethnography of Ethiopia, it is hoped to form a practical reference library of technical and general works, and ultimately to include the standard books on all subjects and of all literatures. It is to be hoped that after the war, when the rehabilitation of libraries in many parts of the world will demand a great cooperative effort, the needs of Ethiopia will not be overlooked. 